\title{
Detection of microbial contamination in chicken meat from local markets in Surabaya, East Java, Indonesia
}

\author{
Dhandy Koesoemo Wardhana ${ }^{1}$ (D) Ajeng Erika Prihastuti Haskito², Muhammad Thohawi Elziyad Purnama3 (D), \\ Devi Ayu Safitri4 ${ }^{\mathbb{D}}$ and Suwaibatul Annisa4 ${ }^{4}$
}

\begin{abstract}
1. Department of Veterinary Sciences, Division of Veterinary Public Health, Faculty of Veterinary Medicine, Universitas Airlangga, Surabaya 60115, Indonesia; 2. Laboratorium of Veterinary Public Health, Faculty of Veterinary Medicine, Universitas Brawijaya, Malang 65151, Indonesia; 3. Department of Veterinary Sciences, Division of Veterinary Anatomy, Faculty of Veterinary Medicine, Universitas Airlangga, Surabaya 60115, Indonesia; 4. Faculty of Veterinary Medicine, Universitas Airlangga, Surabaya 60115, Indonesia.

Corresponding author: Dhandy Koesoemo Wardhana, e-mail: dhandy.koesoemo.wardhana@fkh.unair.ac.id Co-authors: AEPH: drherika1989@gmail.com, MTEP: thohawi@fkh.unair.ac.id, DAS: deviayus13@gmail.com, SA: suwaibatul.annisa@gmail.com
\end{abstract}

Received: 21-07-2021, Accepted: 02-11-2021, Published online: 20-12-2021

doi: www.doi.org/10.14202/vetworld.2021.3138-3143 How to cite this article: Wardhana DK, Haskito AEP, Purnama MTE, Safitri DA, Annisa S (2021) Detection of microbial contamination in chicken meat from local markets in Surabaya, East Java, Indonesia, Veterinary World, 14(12): 3138-3143.

\begin{abstract}
Background and Aim: Chicken meat can be contaminated by microorganisms anywhere in the supply chain, from farm to market, and these microorganisms can be transmitted to humans through direct contact, contact with the environment, and food consumption. The microbial contamination has a serious impact on public health. This study aimed to analyze the microbial contamination of chicken meat sampled from local markets in Surabaya, East Java, Indonesia.

Materials and Methods: A total of 60 samples of fresh chicken meat obtained from 10 traditional markets (six samples per market) were examined for the presence of bacteria. Staphylococcus aureus, Salmonella spp., and Escherichia coli were identified using Gram staining, culturing, and biochemical tests. The most probable number (MPN) method was used to identify E. coli.
\end{abstract}

Results: Most chicken meat samples were positive for $S$. aureus (58.3\%), Salmonella spp. (48.3\%), and E. coli (40\%). The samples were considered positive for $E$. coli if the MPN value was higher than $1 \times 10^{1} \mathrm{CFU} / \mathrm{g}$.

Conclusion: High microbial contamination was found in all the chicken meat sampled from local markets in Surabaya. Such contamination can lead to foodborne diseases so, proper hygiene and sanitation standards should be followed from slaughterhouses to the end-users.

Keywords: chicken meat, local markets, microbial contamination, public health, Surabaya.

\section{Introduction}

Poultry meat products are widely consumed worldwide due to their high nutrition level, relatively low-cost production, and short cooking process [1]. Chickens are raised for meat and serve as a low-acid food that is rich in nutrients, phosphorus, other minerals, and B-complex vitamins [2]. Chicken is an excellent source of animal protein with low lipid content and high biological value, which contains all the essential amino acids and unsaturated fatty acids required for a human diet [3]. Chicken meat is widely popular in Indonesia, where an average of 1.11 million tons of it is consumed per year, with production reaching 1.48 million tons per year. Chicken meat is an affordable source of animal protein, yet it is also easily damaged, as the rapid growth of microorganisms can alter its quality [4].

Copyright: Wardhana, et al. Open Access. This article is distributed under the terms of the Creative Commons Attribution 4.0 International License (http://creativecommons.org/licenses/ by/4.0/), which permits unrestricted use, distribution, and reproduction in any medium, provided you give appropriate credit to the original author(s) and the source, provide a link to the Creative Commons license, and indicate if changes were made. The Creative Commons Public Domain Dedication waiver (http:// creativecommons.org/publicdomain/zero/1.0/) applies to the data made available in this article, unless otherwise stated.
Fresh chicken meat is highly perishable due to its physical and chemical properties.

Its abundance of nitrogenous compounds, lipids, carbohydrates, and vitamins, and its high water holding capacity allow the establishment of a suitable environment for microbial growth [5]. Several pathogenic microorganisms, such as Salmonella spp., Campylobacter spp., Staphylococcus aureus, Escherichia coli, and Listeria spp., have been found to contaminate poultry [6]. Diseases originating from animals can spread to humans through indirect environmental contact, direct contact, and/or food consumption [7]. Foodborne illnesses worldwide are caused by foodborne microbial pathogens, which endanger food safety due to the risk of ingesting food, primarily animal products, that are contaminated with vegetative pathogens or their toxins. Most of these microbes have zoonotic importance, as they can significantly impact both public health and economic sectors [8]. Rortana et al. [9] reported the prevalence of Salmonella spp. and $S$. aureus in chicken meat in Cambodia at $40.4 \%$ and $46.2 \%$, respectively. A study by Mashak [10] revealed that $16.25 \%$ of chicken meat from Alborz, Iran, was positive for E. coli. The previous studies also stated that several chicken meat samples 
from local markets in Indonesia presented microbial contamination, which included S. aureus (6.7\%) [11], Salmonella spp. (85\%) [12], and E. coli $(90.03 \%)$ [13]. The contamination of poultry products including raw broiler meat by pathogenic microorganisms, especially bacteria, has become one of the most challenging problems in the food industry worldwide [14]. Poultry meat can be contaminated by different types of microorganisms during operations at meat-processing plants [15]. Contamination can occur during processing, contact with the facility's equipment (e.g., grinders, belts, and saws), contact with food handlers (e.g., hand contact and knives), and exposure to other environmental sources (e.g., air and water) [16]. The number of bacteria contaminating poultry carcasses may decrease or increase between different processing steps at the plants [17].

Various diseases caused by $S$. aureus, E. coli, and Salmonella spp. can develop due to a lack of public knowledge and awareness, especially among traders for safety, health, quality, and halal classification, during the process of meat handling and distribution [18].

This study aimed to analyze microbial contamination in chicken meat samples from several local markets in the Surabaya region.

\section{Materials and Methods \\ Ethical approval}

Ethical approval for animal research was not required as live animals were not used in this study.

\section{Study period and location}

The study was conducted from July 2020 to September 2020. Chicken meat samples were collected from 10 different local markets of Surabaya. The samples were processed at Veterinary Public Health Laboratory, Faculty of Veterinary Medicine Universitas Airlangga.

\section{Sampling}

In this study, chicken meat was sampled using a purposive sampling method based on several criteria, which included meat selection from sellers with poor sanitation levels, low hygiene for the tools used to cut the meat, and frequent direct contact between the meat and market visitors. Fresh samples $(n=60)$ were collected from 10 different local markets of Surabaya, and they were obtained from the surface of chicken meat. The local markets visited were located in the southern, northern, western, eastern, and central parts of the Surabaya region, and six samples were obtained from each market.

\section{Isolation and identification of $\boldsymbol{S}$. aureus}

$S$. aureus was detected by taking $0.1 \mathrm{~mL}$ of samples from the first dilution $\left(10^{-1}\right)$ for total plate count testing. The sample volume was then inoculated into Mannitol Salt Agar (MSA) (Merck 1.05404.0500) and was incubated at $35^{\circ} \mathrm{C}$ for $24 \mathrm{~h}$. Yellow colonies growing on the MSA were described as positive
S. aureus, while red colonies represented other species of Staphylococcus [19]. The suspected colonies were identified by mannitol fermentation, Gram staining, a catalase test, and a coagulase test as per standard protocol [20]. Gram staining was conducted aseptically on the identified colonies. Bacterial identification was confirmed using a Nikon Eclipse E100 LED microscope with $1000 \times$. S. aureus appeared as Grampositive coccus bacteria and was purple in color. The presence of this microbe was also validated by positive catalase and coagulase test results [11].

\section{Isolation and identification of Salmonella spp.}

Detection of Salmonella spp. was carried out by inserting $25 \mathrm{~g}$ of each meat sample into $225 \mathrm{~mL}$ of Lactose Broth (Merck 1.07661.0500 Darmstadt, Germany) and incubating it at $35^{\circ} \mathrm{C}$ for $24 \mathrm{~h}$. Then, a $1 \mathrm{~mL}$ volume of suspension samples was inoculated into $9 \mathrm{~mL}$ of Tetrathionate Broth (TB) (Merck 1.05285.0500 Darmstadt) and was incubated at $35^{\circ} \mathrm{C}$ for $24 \mathrm{~h}$. One TB loop was taken using an inoculating loop; it was streaked onto Bismuth Sulfite Agar (Merck 1.05418.0500 Darmstadt) and was then incubated at $35^{\circ} \mathrm{C}$ for $24 \mathrm{~h}$. The typical Salmonella colonies were analyzed through Gram staining, lysine iron agar (LIA) media (Merck 1.11640.0500 Darmstadt), triple sugar iron agar (TSIA) media (Merck 1.03915.0500 Darmstadt), Simmons citrate agar (Merck 1.02501.0500 Darmstadt), and a urease test for biochemical identification [21-23]. Salmonella spp. isolates showed positive results, as observed in the Simmons citrate agar. The LIA showed a purple slant/purple butt (alkaline), although the butt reaction may have been masked by $\mathrm{H}_{2} \mathrm{~S}$ production. The TSIA showed a red slant/yellow butt (alkaline). The presence of Salmonella spp. was indicated by negative urease test results [23].

\section{Identification of $E$. coli through the most probable number (MPN) method}

Each sample $(25 \mathrm{~g})$ was homogenized in buffered peptone water (Merck 1.07288.5000 Darmstadt, Germany) for the isolation of $E$. coli. One milliliter of the suspension was transferred into $9 \mathrm{~mL}$ of brilliant green bile broth (Merck 1.05454.0500 Darmstadt, Germany) with a Durham tube and was then incubated at $45.5^{\circ} \mathrm{C}$ for $24-48 \mathrm{~h}$. The isolates were suspected to be $E$. coli once the tube was filled with gas. One loop of suspected $E$. coli was taken and streaked onto eosin methylene blue agar (EMBA) (Merck 1.01347.0500 Darmstadt, Germany) and was then incubated at $35^{\circ} \mathrm{C}$ for $24 \mathrm{~h}$. The suspected colonies from each EMBA were transferred into tryptone water (Merck 1.10859.0500 Darmstadt, Germany) for an indole test. The calculation of MPN for $E$. coli was based on tubes with a positive $E$. coli broth dilution using McCrady's tables [18].

\section{Statistical analysis}

The data are presented descriptively in percentages and displayed in tables. 


\section{Results}

Prevalence of $S$. aureus and Salmonella spp. in chicken meat

Out of the 60 chicken meat samples collected in the present study, $35 \mathrm{~S}$. aureus isolates (58.3\%) and 29 Salmonella spp. isolates (48.3\%) were identified using staining, cultural, and biochemical tests. The prevalence of microbial contamination $(S$. aureus and Salmonella spp.) is summarized in Table-1.

\section{Prevalence of $E$. coli in chicken meat}

Identification through the MPN method revealed that out of the 60 chicken meat samples, 24 were positive for $E$. coli $(40 \%)$. The results are summarized in Table-2. The samples were considered positive if the MPN was higher than $1 \times 10^{1} \mathrm{CFU} / \mathrm{g}$, based on the Indonesian National Standard [24].

\section{Discussion}

Many zoonotic foodborne illnesses are transmitted through chicken meat worldwide, and not only they have a severe impact on public health, but they also impose huge costs on the economy [25]. Some important pathogens associated with these illnesses are S. aureus, Salmonella spp., Campylobacter spp., Listeria monocytogenes, and E. coli [8]. This study, which investigated chicken meat contamination in relation to foodborne diseases, showed positive results for $S$. aureus (58.3\%), Salmonella spp. (48.3\%), and E. coli $(40 \%)$ in samples derived from local markets in Surabaya.

In particular, the prevalence of $S$. aureus $(58.3 \%)$ in chicken meat from the 10 Indonesian markets was higher than that found in raw chicken meat sold in Ghana (9.2\%), as reported by Pesewu et al. [14]. In addition, Kim et al. [26] reported that out of 200

Table-1: Results of bacterial contamination in chicken meat.

\begin{tabular}{lcc}
\hline Laboratory result & \multicolumn{2}{c}{ Bacterial contamination } \\
\cline { 2 - 3 } & $\begin{array}{c}\text { Staphylococcus } \\
\text { aureus }\end{array}$ & $\begin{array}{c}\text { Salmonella } \\
\text { spp. }\end{array}$ \\
\hline Positive sample $(\mathrm{n}=60)$ & 35 & 29 \\
\% positive sample & 58.3 & 48.3 \\
\hline
\end{tabular}

chicken meat samples collected in South Korea, 94 were found to be positive (47\%) for $S$. aureus. This number was lower compared to the value reported in Savariraj et al. [20], where around $66.67 \%$ of samples obtained from in retail outlets in Chennai, India, resulted positive for $S$. aureus.

It is hypothesized that $S$. aureus causes infections primarily in humans. This pathogen has been identified as the cause of staphylococcal food poisoning, which is a type of gastroenteritis due to the consumption of meat containing one or more preformed staphylococcal enterotoxins [27].

$S$. aureus transmission may occasionally occur in the community through the consumption or handling of contaminated foods. Severe foodborne diseases caused by this bacterium have been explicitly demonstrated to develop in healthy individuals for years [28,29]. The contamination of meat with $S$. aureus occurs as a result of poor hygiene during slaughter and handling, and also because of the poor quality of the water used during meat processing. It can occur during several phases throughout the process, including meat production, slaughter, handling, and marketing to consumers [30].

The zoonotic transmission of $S$. aureus from poultry has typically been investigated in regard to antimicrobial resistance. This is considered a crucial issue in the poultry industry due to its impact on public health and because it poses a challenge to medical and veterinary professionals globally [31].

Out of the 60 chicken meat samples examined in this study, 29 (48.3\%) resulted positive for Salmonella strains. This prevalence of contamination was higher than that found in studies conducted in other countries, which have reported a prevalence of 10.8\% [14] for Salmonella in chicken meat sold in Korle Gonno, Accra (Ghana), and of 9.5\% [32] in that sold in Chongqing, China.

Salmonella is a significant zoonotic pathogen that causes human gastroenteritis outbreaks, with occasional cases worldwide [33]. Salmonella infections are frequently correlated with the ingestion of contaminated animal products [34]. Chicken products and raw, or undercooked, eggs have been identified as potential

Table-2: Results of Escherichia coli in chicken meat.

\begin{tabular}{lcccc}
\hline S. No. & Market code & Mean of MPN value for each market (CFU/G) & Positive sample (n=60) & Percentage \\
\hline 1. & M & $>1100$ & 6 & 100 \\
2. & PG & 120 & 1 & 16.7 \\
3. & K & $<3$ & 0 & 0 \\
4. & G & 3.7 & 0 & 0 \\
5. & WK & 454 & 3 & 50 \\
6. & BB & 228 & 2 & 33.3 \\
7. & GS & 18 & 0 & 0 \\
8. & PK & 17.4 & 6 & 0 \\
9. & B & $>1100$ & 6 & 100 \\
10. & LS & $>1100$ & 24 & 100 \\
Total & & & 6 & 40
\end{tabular}

Standard limit MPN $=1 \times 10^{1} \mathrm{CFU} / \mathrm{G}$ [24]. MPN=Most probable number 
transmitters of this bacterium in humans based on previous studies and epidemiological investigations [35,36]. Salmonella enteritidis, Salmonella typhimurium, Salmonella enteritica serotype Newport, Salmonella enterica serovar Infantis, Salmonella serovar Montevideo, Salmonella enterica subsp. enterica Serovar Heidelberg, Salmonella enteritica serotype Senftenberg, and Salmonella enteritica serovar Schwarzengrund are serotypes regularly isolated in different countries, frequently from chicken carcasses, other cut parts, and by-products [37]. The most prevalent serotypes have been shown to cause enteritis and are responsible for foodborne infections [38].

Out of the 60 chicken meat samples investigated in this study, $24(40 \%)$ resulted positive for E. coli contamination, with a number of germs exceeding $1 \times 10^{1} \mathrm{CFU} / \mathrm{g}$ (Table-2). Ayodele et al. [39] claimed that no E. coli was detected in chicken meat from a retail market in Ibadan, Nigeria, while Rahman et al. [40] reported that $63.5 \%$ of the chicken meat samples were collected in Bangladesh tested positive for E. coli. Rahmahani et al. [41] conducted a study in traditional markets in Surabaya, East Java (Indonesia), and discovered that $96.7 \%$ of domestic chicken also contained this bacterium. This high detection rate indicates that chicken meat received from market was unsafe for human consumption, based on the prescribed limits [42].

Animal-derived food is frequently contaminated with E. coli bacteria, which are found in the typical intestinal flora of animals and humans. This bacterium may contribute to prevent the development of harmful organisms in the gastrointestinal tract. Certain strains of $E$. coli frequently become pathogenic due to the pathogenic and virulent properties of several genes included in transmissible genetic elements [43]. Diarrhea, urinary tract infections, sepsis, and meningitis can be caused by pathogenic E. coli strains [44].

These infections are likely to be spread by workers through processing equipment, such as blades and cutting boards, and poor hygiene and sanitation [45]. Contamination can occur during the slaughtering process through direct contact with the slaughterhouse workers' hands, water, and equipment [46]. The high contamination levels observed in this study may be due to the manual slaughter and butchering of animals at slaughterhouses and markets. Indeed, this contaminating flora originates mainly from the animals' skins, from the carcasses handled, and from direct contact with dirty work areas during slaughtering operations [47]. The presence of bacteria in meat-processing equipment and associated surfaces may also contribute to meat contamination at the markets [48].

The poultry industry is a vertically integrated system of production, processing, and distribution. In the broiler farming business, this system enables producers to integrate various biosecurity and sanitation techniques, housing technology, and feeding regimens to improve food safety [26]. These emphasize the importance of providing adequate training in food hygiene to those who handle this type of food, to avoid unsafe practices (such as cross-contamination or insufficient cooking), and thus reduce the risks for consumers [29]. Cross-contamination can be avoided by maintaining high hygiene and sanitation standards during food processing [49].

\section{Conclusion}

From the data acquired in this study, it can be concluded that high microbial contamination was present in all the 60 chicken meat samples collected from local markets in Surabaya. Specifically, the samples were contaminated by S. aureus (58.3\%), Salmonella spp. (48.3\%), and E. coli $(40 \%)$. Therefore, it is recommended to implement the hazard analysis critical control points system and food hygiene practices during food handling and processing. Further research is required to fully comprehend the dynamics of this type of contamination occurring within the food chain.

\section{Authors' Contributions}

DKW, AEPH, MTEP, DAS, and SA: Carried out the main research works. MHE: Performed the analysis of data. DKW, DAS, and SA: Prepared the manuscript. DKW: Revised the manuscript. All authors have read and approved the final manuscript.

\section{Acknowledgments}

The authors would like to thank Universitas Airlangga, Surabaya, Indonesia, for funding this study (Grant number 346/UN3/2020) and Veterinary Public Health Laboratory, Faculty of Veterinary Medicine, Universitas Airlangga, Indonesia, for providing the facilities for the study.

\section{Competing Interests}

The authors declare that they have no competing interests.

\section{Publisher's Note}

Veterinary World remains neutral with regard to jurisdictional claims in published institutional affiliation.

\section{References}

1. Huang, X. and Ahn, D.U. (2018) The incidence of muscle abnormalities in broiler breast meat: A review. Korean $J$. Food Sci. Anim. Resour., 38(5): 835-850.

2. Gamble, H.R. (2015) Trends in food production practices relative to foodborne parasites. In: Foodborne Parasites in the Food Supply Web. Woodhead Publishing, Sawston, United Kingdom. p11-22.

3. Takma, D.K. and Korel, F. (2019) Active packaging films as a carrier of black cumin essential oil: Development and effect on quality and shelf-life of chicken breast meat. Food Packag. Shelf Life, 19: 210-217.

4. Karamah, E.F. and Wajdi, N. (2018) Application of ozonated water to maintain the quality of chicken meat: Effect of exposure time, temperature, and ozone concentration. Vol. 67. In: E3S Web of Conferences. p04044.

5. Odeyemi, O.A., Alegbeleye, O.O., Strateva, M. and Stratev, D. (2020) Understanding spoilage microbial community and spoilage mechanisms in foods of animal origin. 
Compr. Rev. Food Sci. Food Saf., 19(2): 311-331.

6. Bhaisare, D.B., Thyagarajan, D., Churchil, R.R. and Punniamurthy, N. (2014) Bacterial pathogens in chicken meat: Review. Int. J. Life Sci. Res., 2(3): 1-7.

7. Chlebicz, A. and Sli Zewska, K. (2018) Campylobacteriosis, salmonellosis, yersiniosis, and listeriosis as zoonotic foodborne diseases: A review. Int. J. Environ. Res. Public Health, 15(5): 1-28.

8. Abebe, E., Gugsa, G. and Ahmed, M. (2020) Review on major foodborne zoonotic bacterial pathogens. J. Trop. Med., 2020: 4674235.

9. Rortana C., Nguyen-Viet H., Tum S., Unger F., Boqvist S., Dang-Xuan S., Koam S., Grace D., Osbjer K., Heng T., Sarim S., Phirum O., Sophia R. and Lindahl J.F. (2021) Prevalence of Salmonella spp. and Staphylococcus aureus in chicken meat and pork from Cambodian markets. Pathogens, 10(5): 556.

10. Mashak, Z. (2018) Prevalence and antibiotic resistance of Escherichia coli O157: $\mathrm{H} 7$ isolated from raw meat samples of ruminants and poultry. J. Food Nutr. Res., 6(2): 96-102.

11. Karisma U., Wiqoyah N. and Pusarawati S. (2021) Prevalence of Escherichia Coli, Salmonella spp. Staphylococcus aureus bacteria in chicken meat of traditional market Surabaya city. J. Ilmu Teknol. Kesehatan, 8(2): 193-204.

12. Yulistiani R., Praseptiangga D., Supyani and Sudibya. (2019) Occurrences of Salmonella spp. and Escherichia coli in chicken meat, intestinal contents and rinse water at slaughtering place from traditional market in Surabaya, Indonesia. Vol. 633. In: IOP Conference Series: Materials Science and Engineering. p012007.

13. Wardhana, D.K., Effendi, M.H., Harijani, N. and HongKean, O. (2020) Detection of extended-spectrum-beta-lactamase (ESBL) producing Escherichia coli in meat chicken from traditional market in Surabaya, East Java, Indonesia. Indian J. Public Health Res. Dev., 11(1): 1353-1357.

14. Pesewu G.A., Quaynor E.B., Olu-Taiwo M.A., AnimBaidoo I. and Asmah R.H. (2018) Bacterial contaminants of raw broiler meat sold at Korle-Gonno, Accra, Ghana. Int. Food Res. J., 25(4): 1758-1762.

15. Maharjan, S., Rayamajhee, B., Chhetri, V.S., Sherchan, S.P., Panta, O.P. and Karki, T.B. (2019) Microbial quality of poultry meat in an ISO 22000: 2005 certified poultry processing plant of Kathmandu valley. Int. J. Food Contam. 6: 8.

16. Kim, J.H. and Yim, D.G. (2016) Assessment of the microbial level for livestock products in retail meat shops implementing HACCP system. Korean J. Food Sci. Anim. Resour., 36(5): 594-600.

17. Althaus, D., Zweifel, C. and Stephan, R. (2017) Analysis of a poultry slaughter process: Influence of process stages on the microbiological contamination of broiler carcasses. Ital. J. Food. Saf., 6(4): 7097.

18. Soepranianondo, K., Wardhana, D.K., Budiarto and Diyantoro. (2019) Analysis of bacterial contamination and antibiotic residue of beef meat from city slaughterhouses in East Java province, Indonesia. Vet. World, 12(2): 243-248.

19. Jawetz, E., Melnick, J.L. and Adelberg, E.A. (2007) Medical Microbiology. 24 $4^{\text {th }}$ ed. McGraw-Hill, New York.

20. Savariraj, W.R., Ravindran, N.B., Kannan, P. and Rao, V.A. (2020) Occurrence and enterotoxin gene profiles of Staphylococcus aureus isolated from retail chicken meat. Food Sci. Technol. Int., 27(7): 619-625.

21. Hassanein, R., El-Malek, S.F.H., Mohamed, A.M.A. and Elsayh, K.I. (2011) Detection and identification of Salmonella Species in minced beef and chicken meats by using multiplex PCR in Assiut city. Vet. World, 4(1): 5-11.

22. Ishihara, K., Nakazawa, C., Nomura, S.S., Elah, S., Yamashita, M. and Fujikawa, H. (2020) Effects of climatic elements on Salmonella contamination in broiler chicken meat in Japan. J. Vet. Med. Sci., 82(5): 646-652.

23. Supryatno, A., Hadi, U.K. and Murtini, S. (2018) Potency of cockroaches (Periplaneta americana and Blattella germanica) on the ship as vector of salmonellosis in Baubau port. J. Indones. Vet. Res., 2(2): 63-69.

24. The National Standardization Agency of Indonesia (Badan Standarisasi Nasional-BSN). (2009) Maximum Limit of Microbial Contamination in Food, SNI 7388: 2009. Jakarta, Indonesia: The National Standardization Agency of Indonesia (Badan Standarisasi Nasional-BSN). p10-11.

25. Álvarez-Astorga, M., Capita, R., Alonso-Calleja, C., Moreno, B., Del, M. and García-Fernández, C. (2002) Microbiological quality of retail chicken by-products in Spain. Meat Sci., 62(1): 45-50.

26. Kim, Y.B., Seo, K.W., Jeon, H.Y., Lim, S.K. and Lee, Y.J. (2018) Characteristics of the antimicrobial resistance of Staphylococcus aureus isolated from chicken meat produced by different integrated broiler operations in Korea. Poult. Sci., 97(3): 962-969.

27. Seok, K. and Bohach, G.A. (2007) Staphylococcus aureus. In: Doyle, M.P. and Beuchat, R.L., editors. Food Microbiology: Fundamentals and Frontiers. $3^{\text {rd }}$ ed. ASM Press, Washington DC. p493.

28. Capita, R. and Alonso-Calleja, C. (2013) Antibioticresistant bacteria: A challenge for the food industry. Crit. Rev. Food Sci. Nutr., 53(1): 11-48.

29. Buzon-Duran, L., Alonso-Calleja, C., Riesco-Pelaez, F. and Capita, R. (2017) Effect of sub-inhibitory concentrations of biocides on the architecture and viability of MRSA biofilms. Food Microbiol., 65: 294-301.

30. Endale, B.G. and Hailay, G. (2013) Assessment of bacteriological quality of meat contact surfaces in selected butcher shops of Mekelle city, Ethiopia. J. Environ. Occup. Sci., 2(2): 61-66.

31. Ruban, S.W. and Fairoze, N. (2011) Effect of processing conditions on microbiological quality of market poultry meats in Bangalore, India. J. Anim. Vet. Adv., 10(2): 188-191.

32. Chen, T., Jiang, J., Ye, C., Xie, J., Chen, X., Xu, D., Zeng, Z., Peng, Y., Hu, D.L. and Fang, R. (2019) Genotypic characterization and antimicrobial resistance profile of Salmonella isolated from chicken, pork and the environment at abattoirs and supermarkets in Chongqing, China. BMC Vet. Res., 15(1): 456 .

33. Zishiri, O.T., Mkhize, N. and Mukaratirwa, S. (2016) Prevalence of virulence and antimicrobial resistance genes in Salmonella spp. isolated from commercial chickens and human clinical isolates from South Africa and Brazil. Onderstepoort. J. Vet. Res. 83(1): a1067.

34. Pires, S.M., Vieira, A.R., Hald, T. and Cole, D. (2014) Source attribution of human salmonellosis: An overview of methods and estimates. Foodborne Pathog. Dis., 11(9): 667-676.

35. Fallah, S.H., Asgharpour, F., Naderian, Z. and Moulana, Z. (2013) Isolation and determination of antibiotic resistance patterns in non-typhoid Salmonella spp isolated from chicken. Int. J. Enteric Pathog., 1(1): 17-21.

36. Cabral, C.C., Conte-Junior, C.A., Silva, J.T. and Paschoalin, V.M.F. (2014) Salmonella spp. contamination in fresh pork and chicken sausages marketed in Niteroi and Rio de Janeiro, Brazil. J. Verbrauch Lebensm., 9(3): 243-249.

37. Foley, S.L., Nayak, R., Hanning, I.B., Johnson, T.J., Han, J. and Ricke, S.C. (2011) Population dynamics of Salmonella enterica serotypes in commercial egg and poultry production. Appl. Environ. Microbiol., 77(13): 4273-4279.

38. Antunes, P., Mourao, J., Campos, J. and Peixe, L. (2016) Salmonellosis: The role of poultry meat. Clin. Microbiol. Infect., 22(2): 110-121.

39. Ayodele, O.A., Deji-Agboola, A.M., Akinduti, P.A. and Faneye, A.O. (2019) Phylo-diversity of prevalent human E. coli $\mathrm{O} 157$ : $\mathrm{H} 7$ with strains from retailed meat and fish in selected markets in Ibadan Nigeria. J. Immunoassay Immunochem., 41(2): 117-131.

40. Rahman, M.M., Husna, A., Elshabrawy, H.A., Alam, J., Runa, N.Y., Badruzzaman, A.T.M., Banu, N.A., Al 
Mamun, M., Paul, B., Das, S., Rahman, M.M., MahbubE-Elahi, A.T.M., Khairalla, A.S. and Ashour, H.M. (2020) Isolation and molecular characterization of multidrug-resistant Escherichia coli from chicken meat. Sci. Rep., 10(1): 21999.

41. Rahmahani, J., Salamah, Mufasirin, M., Tyasningsih W., and Effendi M.H. (2020) Antimicrobial resistance profile of Escherichia Coli from cloacal swab of domestic chicken in Surabaya traditional market. Biochem. Cell Arch., 20(1): 2993-2997.

42. Adeyanju, G.T. and Ishola, O. (2014) Salmonella and Escherichia coli contamination of poultry meat from a processing plant and retail markets in Ibadan, Oyo State, Nigeria. Springerplus, 3: 139.

43. Erfianto G.I. (2014) Escherichia coli Yang Resisten Terhadap Antibiotikyang Diisolasi Dari Sapi Potong Yang Diimpor Melalui Pelabuhan Tanjung Priok Jakarta [Thesis], Institut Pertanian Bogor. p14.

44. Jawetz, E., Melnick, J.L. and Adelberg, E.A. (2016) Medical Microbiology. 27 $7^{\text {th }}$ ed. McGraw-Hill Education, United States of America.

45. Martínez-Chávez, L., Cabrera-Diaz, E., Pérez-Montaño, J.A., Garay-Martínez, L.E., VarelaHernández, J.J., Castillo, A. and Martínez-Gonzáles, N.E.
(2015) Quantitative distribution of Salmonella spp. and Escherichia coli on beef carcasses and raw beef at retail establishments. Int. J. Food Microbiol., 210: 149-155.

46. Nyamakwere, F., Muchenje, V., Mushonga, B., Makepe, M. and Mutero, G. (2016) Assessment of Salmonella, Escherichia coli, Enterobacteriaceae and aerobic colony counts contamination levels during the beef slaughter process. J. Food Saf., 36(4): 548-556.

47. Ghougal, K., Dib, A.L., Lakhdara, N., Lamri, M., Baghezza, S., Azizi, A., Merrad, R., Zouikri, A., Cheraitia, D., Trouni, M., Soualah, H., Moreno, E., Espigares, E. and Gagaoua, M. (2021) Risk factors related to bacterial contamination by Enterobacteriaceae and fecal coliforms and the prevalence of Salmonella spp. in Algerian farms, slaughterhouses and butcheries: A two-year follow-up study. AIMS Agric. Food., 6(3): 768-785.

48. Evans, J.A., Russel, S.L., James, C. and Corry, J.L. (2004) Microbiological contamination of food refrigeration equipment. J. Food Eng., 62(3): 225-232.

49. Wardhana, D.K., Safitri, D.A., Annisa, S., Harijani, N., Estoepangestie, A.T.S. and Maghfiroh, L. (2021) Prevalence of extended-spectrum beta-lactamases in producing Escherichia coli in beef sold in traditional markets in Surabaya, Indonesia. Biodiversitas, 22(5): 2789-2793.

\section{$* * * * * * * *$}

